9 穴整堂柘榴石は端成分が五種も存在して居名から，n， $\mathrm{G}$ 及び $\mathrm{a}_{0}$ の 物理性質のみでは Alm 分子が相賞量存在すると言ふ外に化學成分に就 て知ることが出來ね，若し何等かの手掛りで Py 及び Gr 网分子が各 10 $\%$ 近く含有し，Sp 及び And 分子は少量であると言ふことが知れりば， $\operatorname{Alm}$ 分于の含量百分比の大姴は知られる。

10 中津川稚柘榴石の如く And 分子 $95 \%$ 以上を含有する場合は， $a_{0}$ の測定のみでも亦届折率の測定のみで当其化學成分の大要は知ることが 出承る， $\mathrm{a}_{0}$ \& $\mathrm{n}$ 女其值が柘榴石族中最高であろからである。

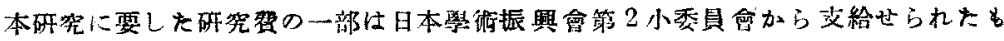
のである。䓜に同會に路し謝意を表する。

\title{
北海道に於ける蛇絞岩に件る優白岩類に就いて (I)
}

理學溥士 鉿 木 醇

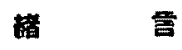

北海道に於ける脊梁山脈の西側に沿方地帶には，日高系，白严系，作羅 系, 神居古潭系及び第三系に屬する諸岩層が略々南北の走向を以て稍々本

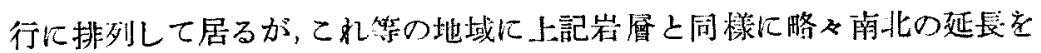
有する渦監基性火成宏が著しく發道してわる事は注目すへきである。姝 に天監，石猚，脆振，日高等の山地に於りる神居古潭系及び侏羅系の發澾す

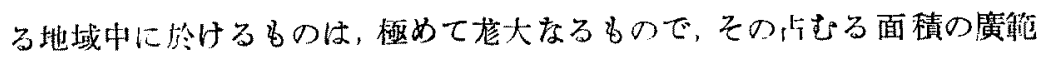
なる事は，本邦全士中他にその例を見ないるのである。

その產狀る見るのに小なるるのは幅數米乃至數十米のレンズ状をなし

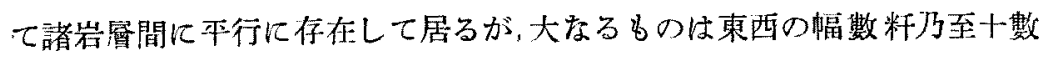




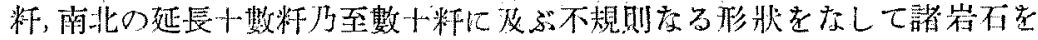
異いて居るもの数笘所を数ふう事が出來る。

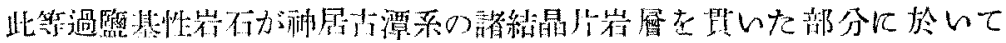

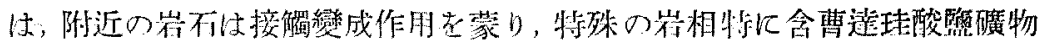

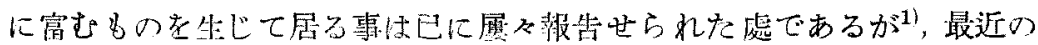

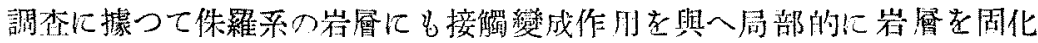
せしめ凡片狀㞸化せしめて居る事賽の少くない事が知らるるに至つた。

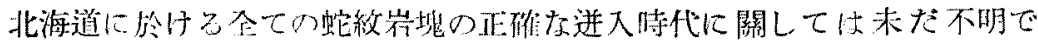
あるが、・諳の事赛 よりして少くとも 侏羅紀以後の地款 變動に件つて生じ たものが少く索い 事が窂はれる。

これ繁の過嬖其 性岩石の一部には

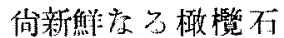
或は輝石制等含む 嫩欖崔又心輝不橄 撜岩が位して居る が，大部分の多の は，現今蛇紋岩に依 つて代装せられて 居ろるのである。 佾此等の蛇紋岩球 第豪表

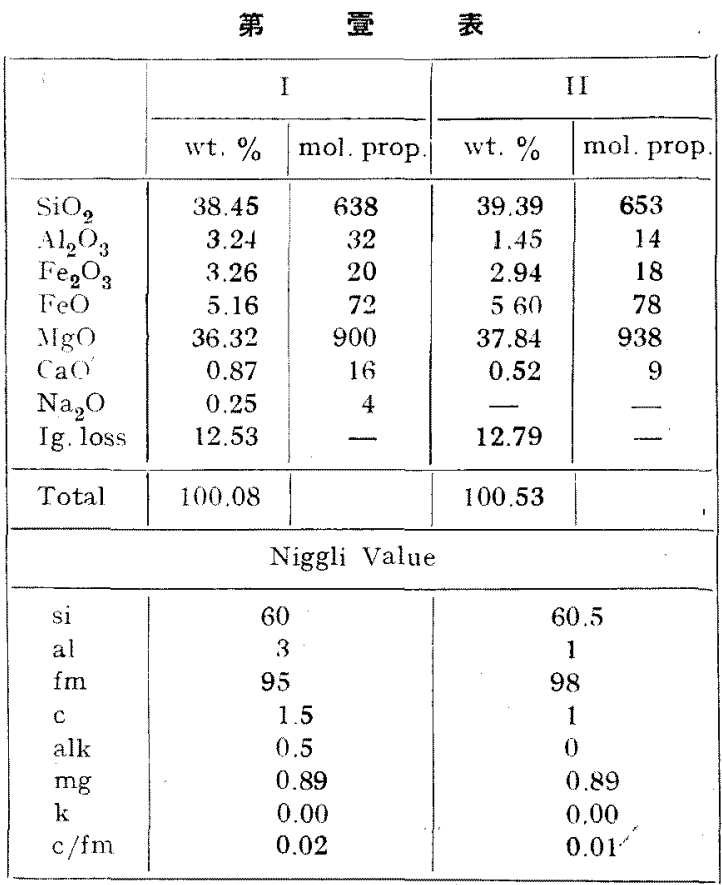

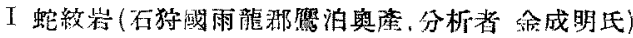

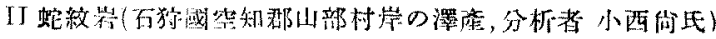

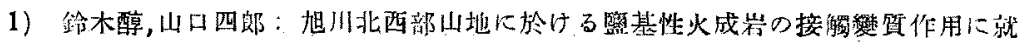

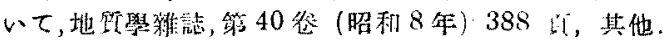


塊狀を示す事が一般であるが部分的には地政變動により影響せられた結 果とも見るべさ蛇䎦片岩, 滑石片岩刃は陽起石片岩等を示して居っ事も見 る事が出隶る。

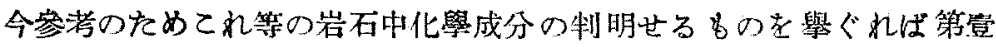
表の如くである。

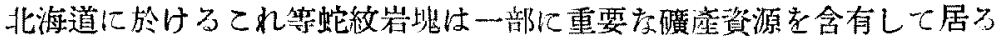
ので現今各方面より注意が向けられて居る。特に日高及び售振川地の柿 魯謨矌床，天監溫根內地方の水銀碛床などその例であるが，近比は更に石

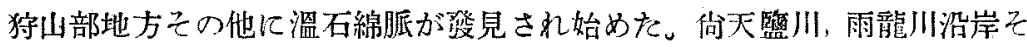
の他に産する砂白金，イリドスミン及び砂格魯謨等いづれも蛇紋岩に源を 墢して居る事は言を俟たない。ニッケルを含有する良質のものは未だ知ら

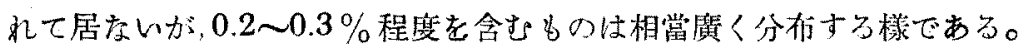
北海道に於ける蛇效岩の墢達する地帶を調查し極めて興味ある事は，蛇 紋岩塊中或はてれに接する地域に多種の優白岩 (leucocrates) 及び優黑岩 (melanocrates) の發達して居る事である1)。特に前者は後者に比して，乙 の數量に於いて遙かに凌駕するるのと信ぜられる。本文に於いては優黑 岩に就いては暂く閤き，特に優白岩に就いてそれ等の性質を記逃する事 とする。

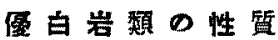

北海道に於ける蛇紋岩に伴心優白岩類は幅一米上り數十米に及ぶ岩脈

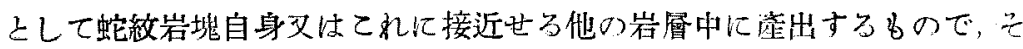
れ等は産狀上り推して，過監基性火成岩几附隨した岩漿分化に上る脈岩上 して貫入したもの上見る事が出來る。本岩類は北海道に於ける蛇紋岩地 带には極めて普遍的に分布するものであるが, 地方的に數量站びに性筫を 筫にするものである。從來知られた處に上れば，北海道に於ける蛇较岩坮

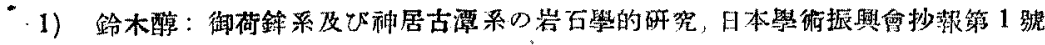
(昭和 14 年) 28 筫. 
中特に格魯謨鐵磺又は石綿胍の罘胎する地域に於いては，この種の偠白岩 類の没達が著しい傾向あり，てれ等特殊礦床成生と優白岩類の買入乙の間 几何等加の因果關係ある事を思はしめるものである”。

向てれ等各種の優白岩類は更に其後の貫入にからるものと思はれる特

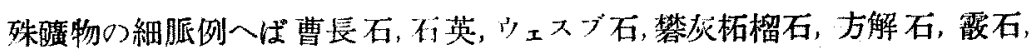
曹灰針石或は沸石等の細脈に上つて買かれれ事璸がある。

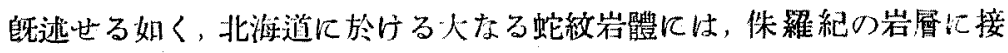

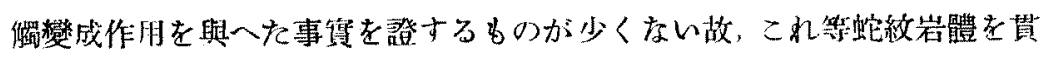

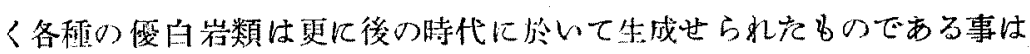
言を侯たをい。總ての優白岩類の黄入を略同時代のものとするや否やは 疑問であるが，優白岩自身の產狀のみに就いて見れば，㱆別山麓に於いて

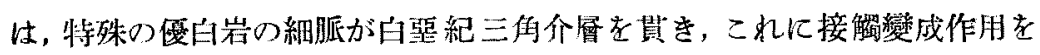

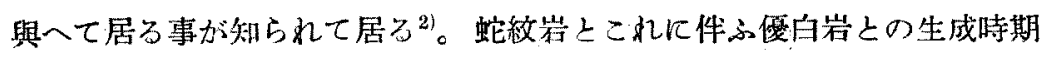
の間に如何孝る隔りがあるかは不明であるが, 若し後者が前者の迸入に引

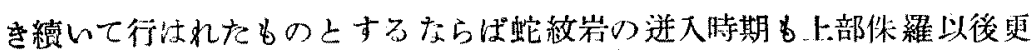

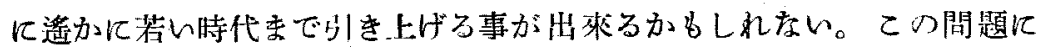
就いては此後更汇各地の地筫調查を必要とするものである。

北海道に於ける蛇皎岩に件ふ各種骤白岩類は外見乳白色乃至灰白色或

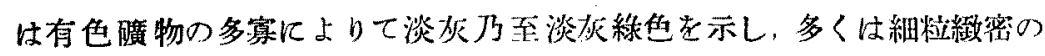

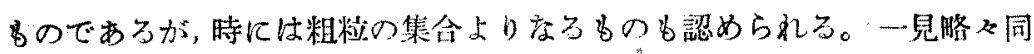
程類の如く見ゆるものでも，礦物成分站びに化罢成分より見れば極めて相 異る性質を示して居る事が少くをん。何れの場合に於いても岩質堅固で あるために比校的周圍の風化した蛇絞岩その他の岩石中に突起して漟出 して居る事が多く，野外に於いて值にその存在知る事が出來る。今各地

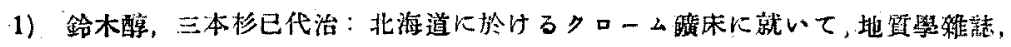
第 46 尞（昭和 14 年) 324 頁.

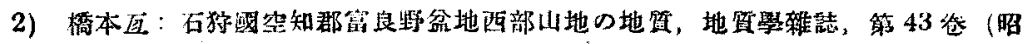
和11年, 509 踝. 
より虐出した为のを岩石學的に綜合すれば大體次の如く分類する事が出 來る。
(A)’曹長岩 (Albitite)
(B) 石英曹長岩 (Quartz-albitite)
(C) 曹長斑岩 (Albitophyre)
(D) 角閃石曹長岩 (Hornblende-albitite)
(E) 曹長石アプライト (Albite-aplite)
(F) トロンメム岩 (Trondhjemite)
(G) ペダマタイト (Pegmatite)
(H) 閃綠岩質アプライト (Diorite-aplite)
(I) 閃緗斑啃岩質アプライト (Diorite gabbro-aplite)
(J) 斑橉岩質アプライト (Gabbro-aplite)
(K) ロヂン岩 (Rodingite)
(L) 各種白色䃪物脈 (White veins)

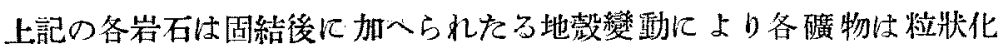
作用を受け，且波状消光或恃屈曲走行つて居るものが少くない。文これ等 の冈更に强い變化を蒙つたものて於いては，岩石全體として熋碎作湖を受

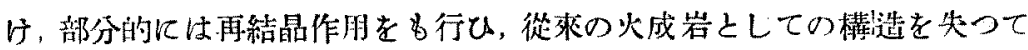
居るものをも認める事が出來る。

\section{(A) 曹長岩 (Albitite)}

北海道に於ける蛇紋岩に伴予優白岩中最も廣く分布するものは曹長岩

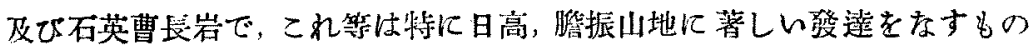
である。それ等の最も代表的のものは日高國沙流川支流二セウ川沿岸，八

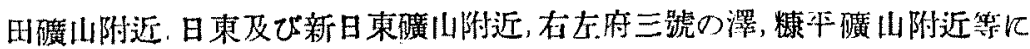
發達して居るが，幅は一米上り數米に及ぶものが最も多い。これ等は何れ す白色乃至灰青白色維密の岩石で曹長石久はこれと石英とを主體となす

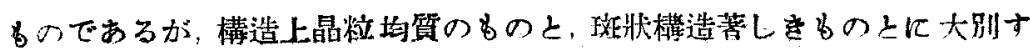


る事が出來る。これ等同者は野外に於いて識別困難であるが，共に極めて

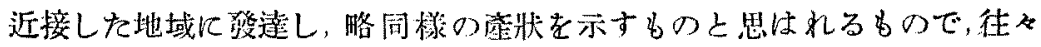
同一岩胍中に於々て部分的にこれ等の性質を示すbのをる見る事が出來 る。又大なる岩脈に於いては，一部が不英或解閃石を含さ岩種に移化す る号本存在する。

緻密疗る曹長岩は $0.1 \sim 0.5 \mathrm{~mm}$ 內外の不規則な曹長石粒の集合體より

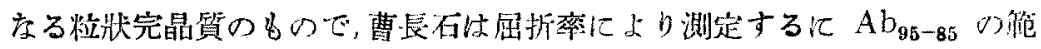
園のものが多い。

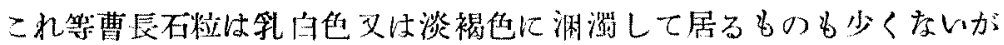
一部には骤めて新鮮である。いづれも緗いアルバィト式双晶を示して居 るが熼帶構造を示すものは稀である。但し部分により波状消光，或は屈曲

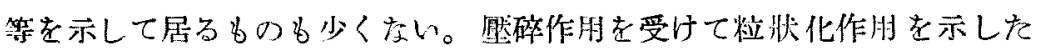

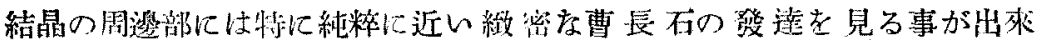
万。

本岩中には稍ヶ多量り緑泥不及び徽量の絹雲母吕有して居る部分が

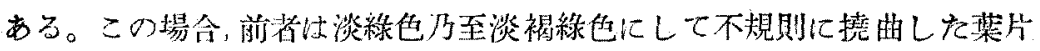

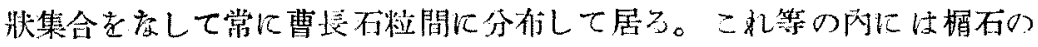
細粒を混じて居る事が䅉るある。

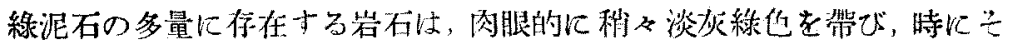

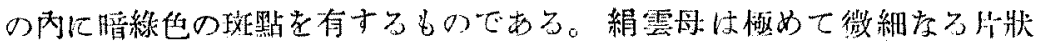
を存して业遍的に散看して居る。

本岩中には往々少量の石英及び作長石考含む事があるが特には全くこ

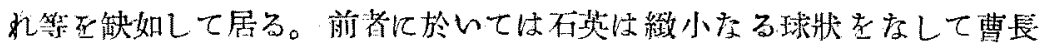

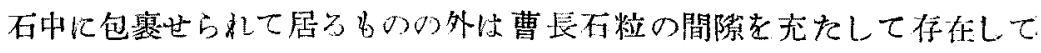

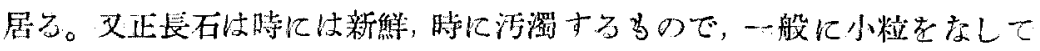
曹與石粒の間に介在して居る。

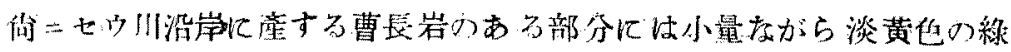




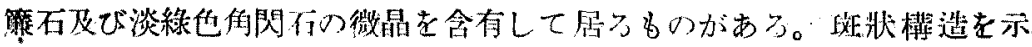

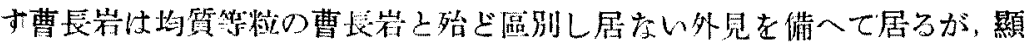
微鏡下に於いては秒々大なっ曹長石の斑晶の間を細粒緻密なる曹長岩篗 石基で埋めて著しい亥状構造を示して居る事圭特質として居る。この程

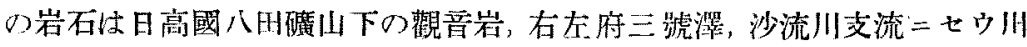

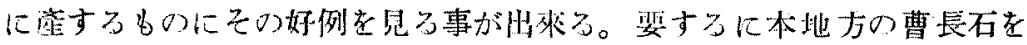

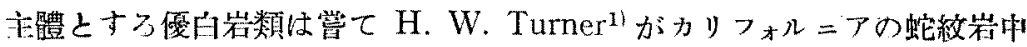
の優白岩類に對し初めて曹長岩 (albitite) 上命名したbの上殆ど同榚の 赀筫交示すbのである。

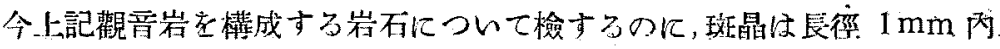

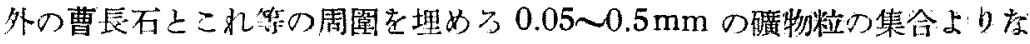
ろ石基とよりなるものである。玟晶をる曹長石は一般に周固が䊑々粒快

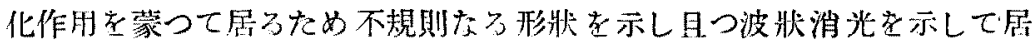

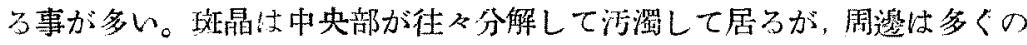
場合新鮮である。石基は主として曹長石，綠泥石，梮石及び絹雲冒を混じ

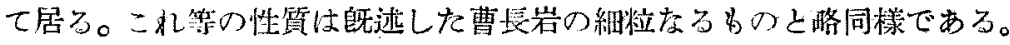

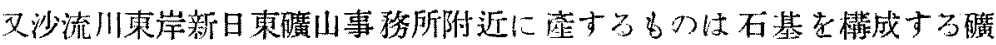

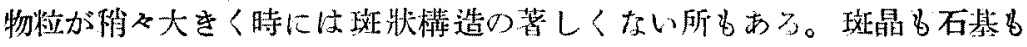

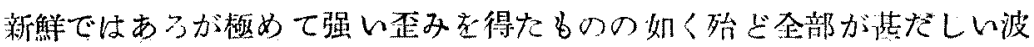

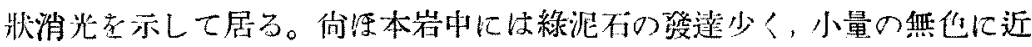

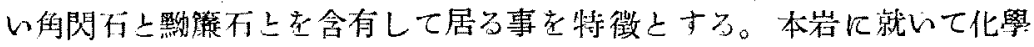

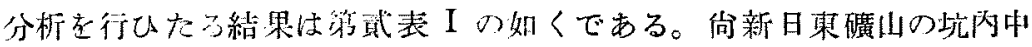

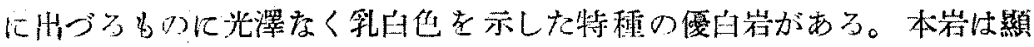

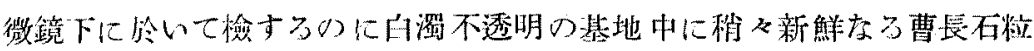
が散點し又極めて小量の綠泥石及び葡得石孛混じ居るbのである。一部

1) H. W. Turner; Notice of some syenitic rocks from California, Amer. Geol. Vol. XVII (1896) 380 兵々力他. 
分份石英の微粒よ

第氠

口在石細脈江㰓力

れて居万が, 岩石成

分上しての石英粒

は殆に゙認められな

い。本䇹はその锒

状站びに岩質より

推して恐らく曹長

岩が蝠入後更に上

开した熱水溶液の

ために變化を受け

在來の曹長石その

他が著しく粘上化

せる8のと䍐はれ

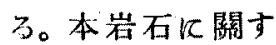

る化學分析の結果

第顶表 II 亿舉

げ、新蘚索る曹長些

この比较に供すつ

事上する。

第式表に於りる 江 分析者小松三郎坻)

\begin{tabular}{|c|c|c|c|c|}
\hline r & \multicolumn{2}{|c|}{1} & \multicolumn{2}{|c|}{11} \\
\hline & wt. $\%$ & mol. prop. & wt. $\%$ & mol prop. \\
\hline $\mathrm{SiO}_{2}$ & 67.17 & 1114 & 57.56 & 955 \\
\hline $\mathrm{TiO}_{2}$ & 0.30 & 4 & 0.10 & 1 \\
\hline $\mathrm{Al}_{2} \mathrm{O}_{3}$ & 18.22 & 178 & 24.96 & 244 \\
\hline $\mathrm{Fe}_{2} \mathrm{O}_{3}$ & 0.46 & 3 & 0.24 & 2 \\
\hline $\mathrm{FeO}^{\circ}$ & 0.65 & 9 & 0.36 & 5 \\
\hline $\mathrm{MnO}$ & 0.06 & 1 & - & - \\
\hline $\mathrm{MgO}$ & 1.08 & 27 & $0 \cdot 72$ & 18 \\
\hline $\mathrm{CaO}$ & 0.92 & 16 & 1.82 & 32 \\
\hline $\mathrm{Na}_{2} \mathrm{O}$ & 9.46 & 153 & 3.61 & 58 \\
\hline $\mathrm{K}_{2} \mathrm{O}$ & 0.33 & 4 & 0.11 & 1 \\
\hline $\mathrm{P}_{5} \mathrm{O}_{5}$ & - & - & - & 一 \\
\hline $\mathrm{H}_{2} \mathrm{O}^{\prime \prime}(+)$ & $0 \cdot 92$ & 51 & 9.62 & - \\
\hline $\mathrm{H}_{2} \mathrm{O} O(-)$ & 0.31 & - & 0.84 & - \\
\hline $\mathrm{CO}_{2}$ & - & - & 0.08 & 2 \\
\hline Total & 99.88 & & 100.02 & \\
\hline \multicolumn{5}{|c|}{ Niggli Values } \\
\hline si & \multicolumn{2}{|c|}{281} & \multicolumn{2}{|c|}{264} \\
\hline al & \multicolumn{2}{|c|}{45} & \multicolumn{2}{|c|}{67.5} \\
\hline $\mathrm{fm}$ & \multicolumn{2}{|c|}{11} & \multicolumn{2}{|r|}{7.5} \\
\hline$c$ & \multicolumn{2}{|c|}{4} & \multicolumn{2}{|c|}{9} \\
\hline alk & \multicolumn{2}{|c|}{40} & \multicolumn{2}{|c|}{16} \\
\hline $\mathrm{mg}$ & \multicolumn{2}{|r|}{0.63} & \multicolumn{2}{|r|}{0.67} \\
\hline $\mathrm{k}$ & \multicolumn{2}{|r|}{0.03} & \multicolumn{2}{|r|}{0.03} \\
\hline $\mathrm{c} / \mathrm{fm}$ & \multicolumn{2}{|r|}{0.36} & \multicolumn{2}{|r|}{1.20} \\
\hline
\end{tabular}

I 曹造岩 (日高四沙流郡平取村新日東碳山事務所附

II 分所せる曹長岩（同上坑内，分析者间比）

二何の分析を比較すタのに後者 II は前者 I に比して老しく珪酸端びに 曹達が減少し，これに反して極めて多量の攀上及び氷分が堬加して居る事

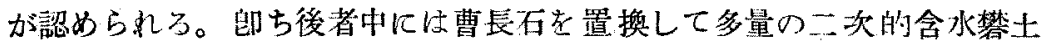

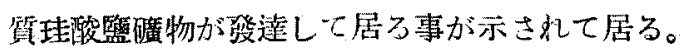

\section{(B) 石英曹長岩 (Quartz-albitite)}

以上は曹長岩中比較的石英に无しきるの或は全くこれ学缺如して居つ 


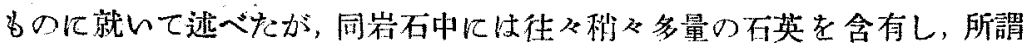

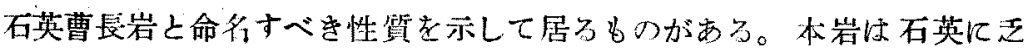

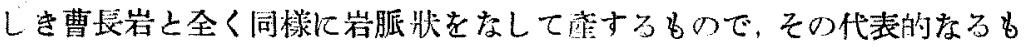

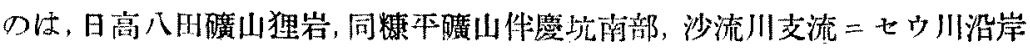

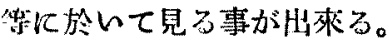

これ等岩脈は一般に一米乃至數米の幅を有するものが多んが八田磺山 狸岩の如きはその幅約 30 米に及んで居る。

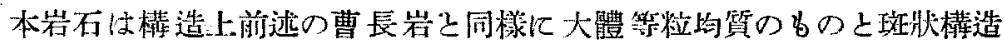
考示するのに分ち得るるので曹長石及び石英它主成分上し，てれに少 量の綵泥石，角閃石，䋧雲母，梢石，其他去有する60であう。石英の大

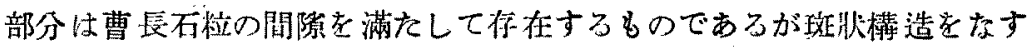
タのに於いては稀に球炏の斑昌をなし居っものが認められる。

八时囕山狸岩は大なる格鲁謨矌床に近接して存在し坑道の一部は同岩

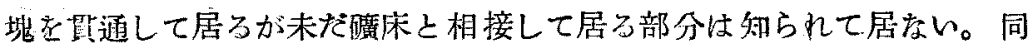
岩は長徑 $1 \mathrm{~mm}$ 內外の不规則な曹長石及び石英を淕晶としこれ等を比較 的粗粒なる $0.5 \mathrm{~mm}$ 冈外の曹長石及び石英粒よりなる石基索以て充填し

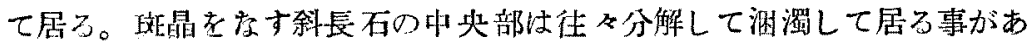

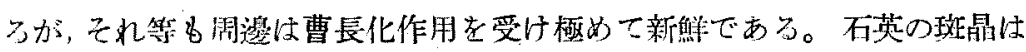
利《球形に近いものも多いが全體とし曹長石の亥晶に比して非常に小量

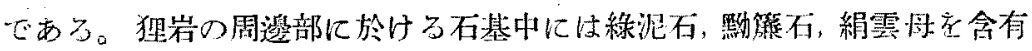
して居るが, 坑们に於いて探集した狸岩中心部のものには上棓のもの0外

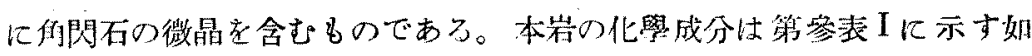
くであろ。

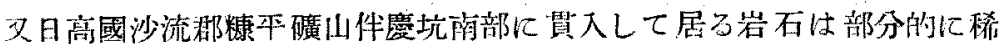
に斑狀構造を示すが大體仗 $0.02 \sim 0.05 \mathrm{~mm}$ 內外の曹長石及び石英を主體

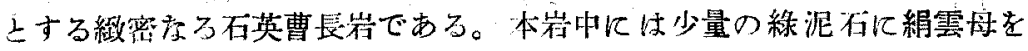

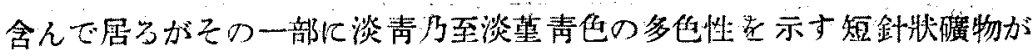




\begin{tabular}{|c|c|c|c|c|}
\hline & 第 & 跑 & 表 & \\
\hline \multirow{2}{*}{ 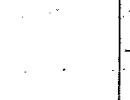 } & \multicolumn{2}{|c|}{1} & \multicolumn{2}{|c|}{ IT } \\
\hline & wt. $\%$ & mol prop & wt. $\%$ & mol prop \\
\hline $\mathrm{SiO}_{2}$ & 70.24 & 1165 & 72.92 & 1209 \\
\hline $\mathrm{TiO}_{2}$ & 0.07 & 1 & 0.16 & 2 \\
\hline $\mathrm{Al}_{2} \mathrm{O}_{3}$ & 16.86 & 165 & 16.69 & 163. \\
\hline $\mathrm{Fe}_{2} \mathrm{O}_{3}$ & 0.14 & 1 & 0.25 & 2 \\
\hline $\mathrm{FeO}$ & 0.86 & 12 & 0.50 & 7 \\
\hline $\mathrm{MnO}$ & $\mathrm{tr}$ & - & tr & - \\
\hline $\mathrm{MgO}$ & 0.73 & 23 & 0.43 & 11 \\
\hline $\mathrm{CaO}$ & 0.92 & 16 & 0.42 & 7 \\
\hline $\mathrm{Na}_{2} \mathrm{O}$ & 6.85 & 110 & 7.43 & 120 \\
\hline $\mathrm{K}_{2} \mathrm{O}$ & 1.94 & 21 & 0.29 & 3 \\
\hline $\mathrm{H}_{2} \mathrm{O}(+)$ & 0.86 & 48 & 0.48 & 27 \\
\hline $\mathrm{H}_{2} \mathrm{O}(-)$ & 9.48 & - & 0.20 & - \\
\hline Total & 99.95 & & 99.77 & \\
\hline \multicolumn{5}{|c|}{ Niggli Values } \\
\hline si & \multicolumn{2}{|c|}{333.8} & \multicolumn{2}{|r|}{383.4} \\
\hline a! & \multicolumn{2}{|r|}{47} & \multicolumn{2}{|r|}{52} \\
\hline $\mathrm{fm}$ & \multirow{2}{*}{\multicolumn{2}{|c|}{$\begin{array}{r}11 \\
4.5\end{array}$}} & \multicolumn{2}{|r|}{$\begin{array}{l}7 \\
2\end{array}$} \\
\hline $\mathrm{c}$ & & & & 2 \\
\hline alk & \multicolumn{2}{|r|}{35.5} & \multicolumn{2}{|r|}{39} \\
\hline $\mathrm{mg}$ & \multicolumn{2}{|r|}{0.62} & \multicolumn{2}{|r|}{0.50} \\
\hline $\mathbf{k}$ & \multicolumn{2}{|r|}{0.16} & \multicolumn{2}{|r|}{0.02} \\
\hline $\mathrm{c} / \mathrm{fm}$ & \multicolumn{2}{|r|}{0.43} & \multicolumn{2}{|r|}{0.32} \\
\hline
\end{tabular}

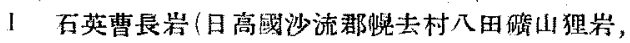
分析者 小松三郎氏)

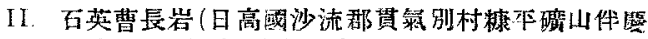
坑消部分析者小松三郎纸)
含まれて居方。本 碑物は延唇性正楅 兩粶を示し且つ弰 光解 $\mathrm{c}: \mathrm{Y}=18 \sim$ $20^{\circ}$ 有し青閃石 (crossite) の性算 を示すめのであ 万。的方本黉物は 石英曹長岩中の一 成分在りし角閃石 が，其後下昇した 曹遾に富さ熱水溶 液の影響によつて 青成石化作用索受 けたるの上思壮れ 万。糠平磄山商の 岩不に關する化學 成分は第会表IIに 示す如くである。

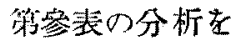

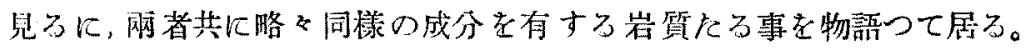

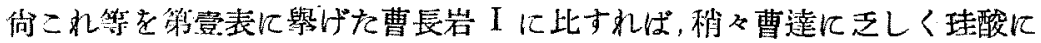

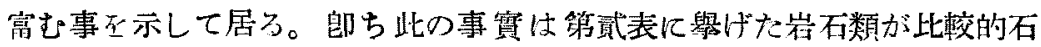
英に富己事に原团する事たるは言を侯たた。

\section{(C) 曹長斑岩 (Albitophyre)}

日高國沙流川支流＝七ウ川中にて得たる白色緻密の一轉石を顯徽鏡下 に於いて檢したのに，同岩舁は曹長石及び石英を主體とし著しい玟狀構造 


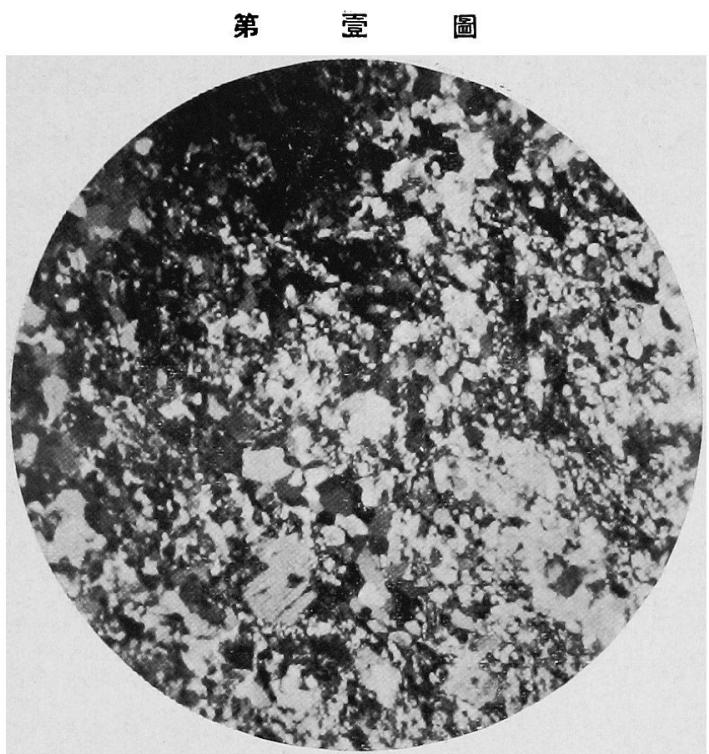

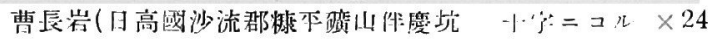

第烡圖

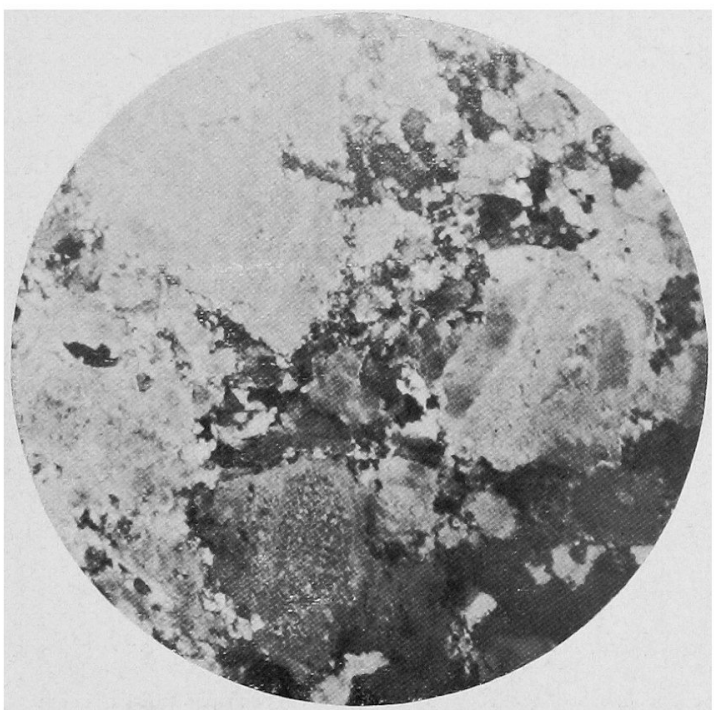

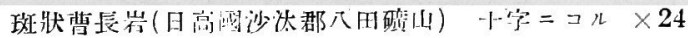




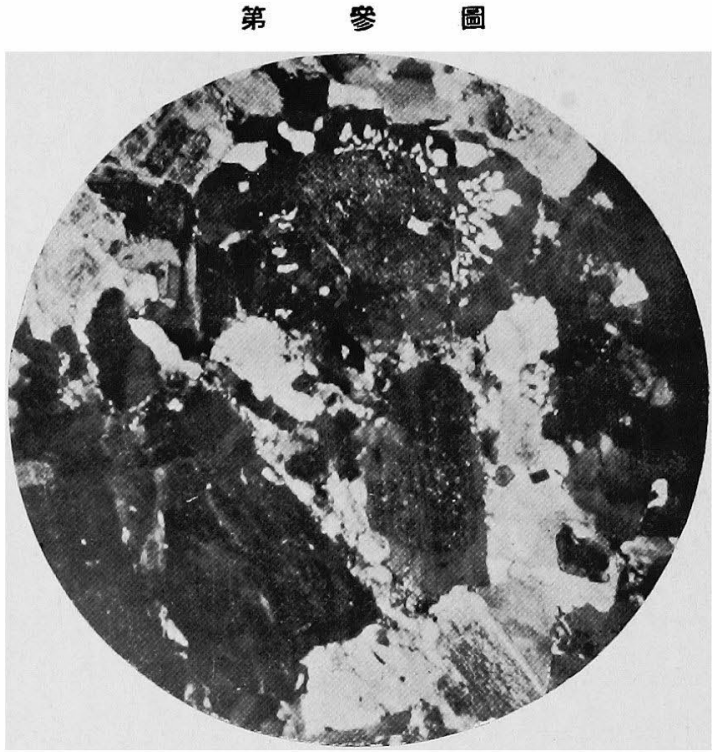

曹長斑岩（日高國沙流郡二ヒウ川）十字ニコル $\times 24$

第

四

圖

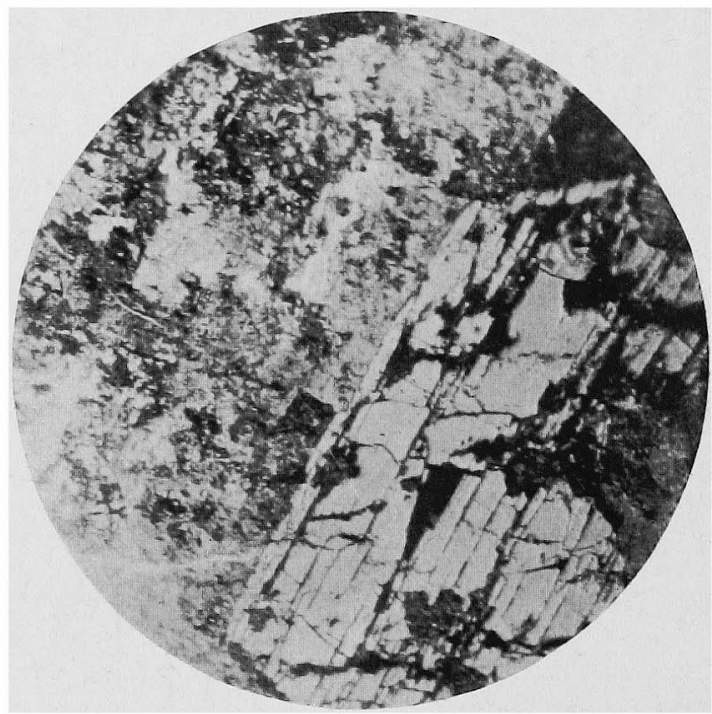

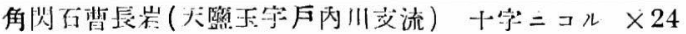




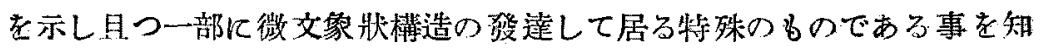
つた。刨ち本岩はその䃫物成分站びに構造より推して最近 H. von Eckermann ${ }^{11}$ によつて定䉝せられた所謂曹長斑岩 (albitophyre) に相賞するも の上見乃事が出來る。

本岩の德の应狀に就いては未だ不明であろが二ヒウ川流域の蛇紋岩中 に他の曹長岩と同椂に岩脈として貫入して居るものである事は想像に蜼 くない。少本地方に於いては未だ本岩の如き微交象狀丵造を示す岩石の

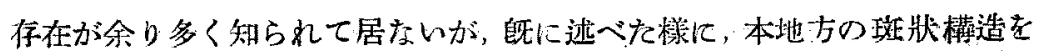

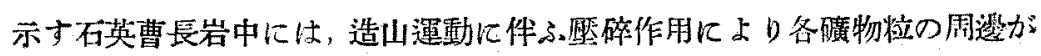
著しく粒狀化作朋䒯蒙つて居るものが少くないから，この種の岩不中には； 在來曹長玟岩としての構造老有して居たものが粒狀化作用の結果その徽 交象狀㮖造を失つたbのがあるか子知れない。

述へえとする二セウ川の曹長斑岩忙粗狀完晶質石でその内に比較的多 量に散點する曹長石斑晶は牛自形を示し長唖 1 2 $\mathrm{mm}$ 附近のものであ る。石英は靖晶しして存在するものは認められないが不基中に曹長石と 相混じて存在し又部分により曹長石よの間に美しき微交象状㰌造を示し

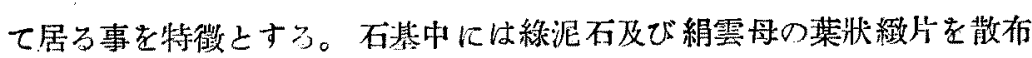
するるのであるが，所により $1 \mathrm{~mm}$ 几達する白雲母含有する事が注目さ n>

本岩に就いての化學分析は未た行はれて居ないが碳物成分立びに割会 より推せば前遮の石英曹長岩と略ぬ同樣の成分を示するのと信ぜらる。

\section{(D) 角閃石曹長岩 (Hornblende-albitite)}

曹長岩又は石英曹長岩中儿微量の解閃石又は青閃石化せる伯閃石の含 まれて居る例に就いて壮已に述べた所であるが，日高國有危府三號の澤，

1) H. von Eckermann: A contribution to the knowledge of the late sodic differentiates of basic eruptives. Jour. Geol. Vol. 46, No. 3, (1938), p. 416, Albitophyre なる語住 1857 年 H. Coquand により初めて用ひらられたのでるが 定義は制然としたものではかつた。 


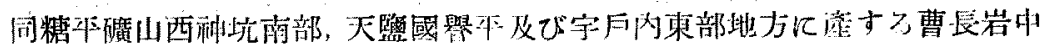

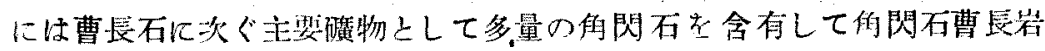

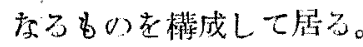

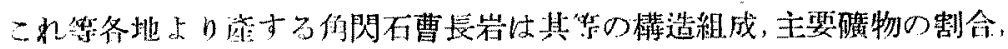

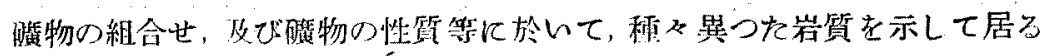

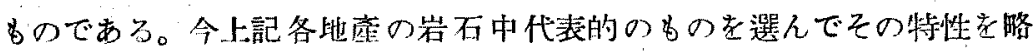
記する事とする。

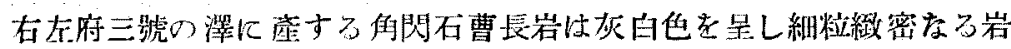
筧条示すbので,その主成分たる曹長石は $1 \mathrm{~mm}$ 以下の不规则なる形態を 示し，又解石は $1 \mathrm{~mm}$ 以下の柱快をなし，その性買は $\mathrm{n}_{1}=1.647, \mathrm{n}_{2}=$ $1.658, c: Z^{\prime}=20^{\circ}, \mathrm{X}=$ 無色， $\mathrm{Y} \fallingdotseq Z=$ 淡灰黄綀色である。

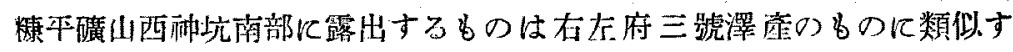

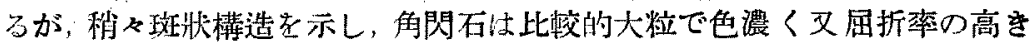
事及び石基中に微量ながら淡綠色の柘榴石考含有して居る事を特徽とす ”。们閃石の性㬏は $\mathrm{n}_{1}=1.654 \mathrm{n}_{2}=1.665, c: Z^{\prime}=20{ }^{\circ} \mathrm{X}=$ 淡褐色, $\mathrm{Y}=$ 淡線芯，Z二綠色である。

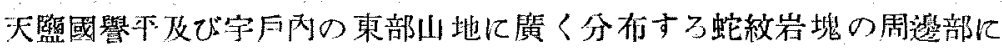

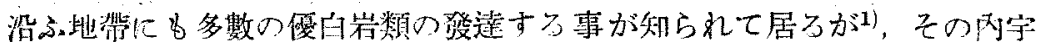
戶肉川支流地域，ハンケナイ川より得たるbのに特程の解不曹長岩が

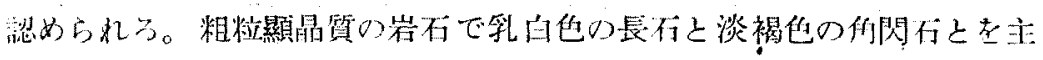

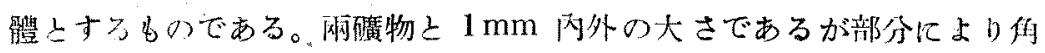

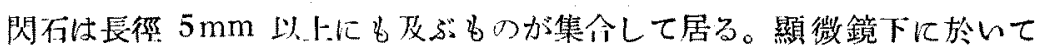

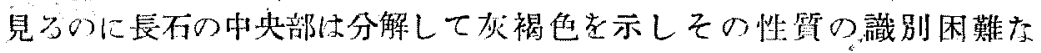

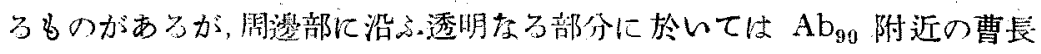

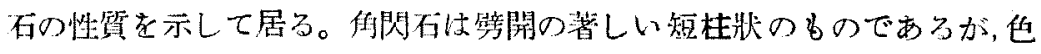

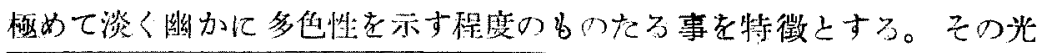

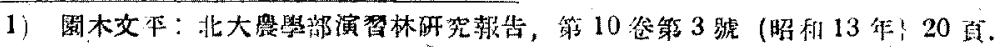


學性は $\mathrm{n}_{1}=1.633, \mathrm{n}_{2}=1.639, c: Z^{\prime}=18^{\circ}$, 光學性正, $\mathrm{X} \fallingdotseq \mathrm{Y}=$ 淡黄袓 色， $\mathrm{Z}=$ 淡褐色， $(+) 2 \mathrm{~V}=77^{\circ}$ である。

本岩石に於いて特簐すべき事は本岩の一部殊に角閃石の粗䊀の集合す

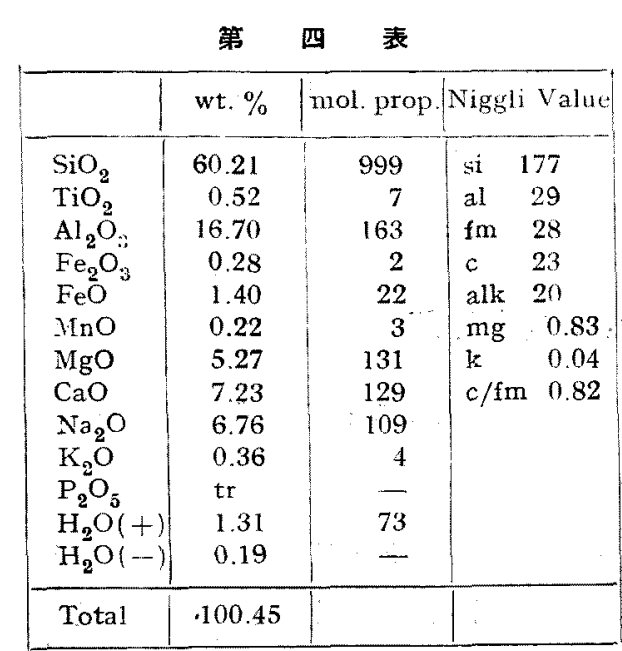

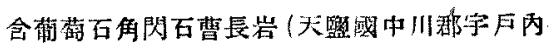
川左支流，分析者 小松三郎氏)
る部分に多量の葡萄石の存

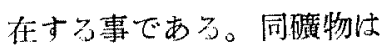
無仙透明で常に曹長石及び 角聞石の間隙索滿をして霅 出し大なる多のは唇徑 $1 \mathrm{~mm}$ 附近である。(001)に

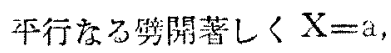
$Z=c$, 屈折率は $\alpha=1.619$, $\beta=1.626, \gamma=1.642, \gamma-\alpha$

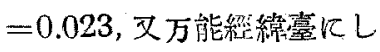
て测定せるに $2 \mathrm{~V}=67^{\circ} て ゙$ ある。一部比蘭萄石含有 する角閃石曹屒岩閵する

化學成分は第四表に示す奶くである。

第四表に示された分析を見るに，本岩石は既に舉げられれ曹鲅岩類に比 して稍ぬ多量の苦土と石灰を含有して居る事老特徴として居る。即ち菬

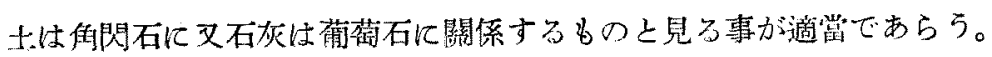

\section{(E) 曹長石アプライト (Albite-aplite)}

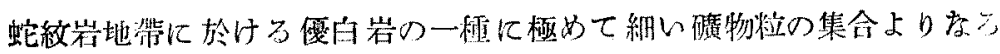

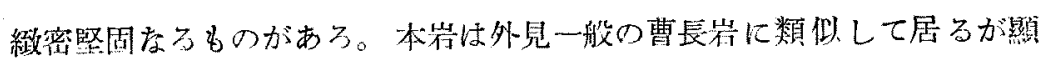
微鏡下に於いて檢するのに $0.05 \sim 0.1 \mathrm{~mm}$ 附近の曾長们集合體よりな

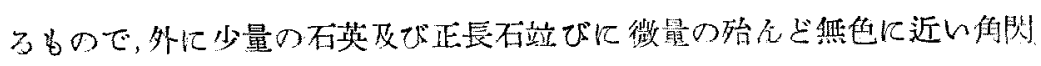

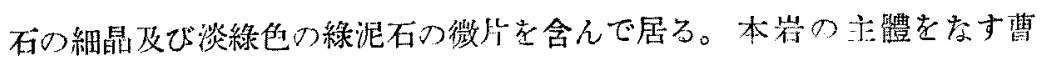

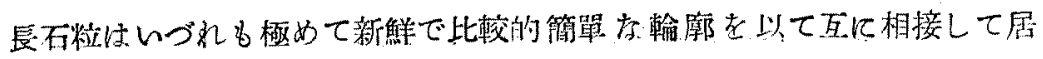




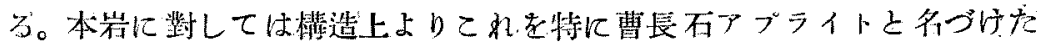
が，成分上或は成因上琶らく一般の曹長岩上密接なる關係を持つものであ

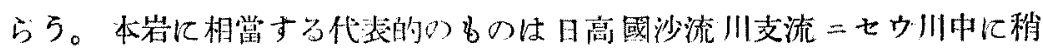

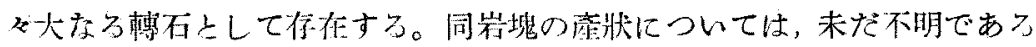
が，附近の曹長岩類之同樣に二セウ川流域に發拴する蛇紋岩塊に關係した 岩脈として貫入したもの上見ろ事が出來る。(未完)

\section{男鹿統の堆皘輪迴 (I)}

$$
\text { 理學缭士 高 橋 純 - }
$$

\section{㒂}

贯

男鹿牛島は一の陸嫘島で, これと本上を結ぶトムボロ砂嘴によつて八郎 潟が抱かれるのである。地形は西方机高く東方に低く、所謂ヶス夕狀を呈 し，西海岸は總壁を好して海蝕の奇景に富み本山 $(716 \mathrm{~m})$ 真山 $(571 \mathrm{~m})$ の 背梁が，これに䡛走し，それょり東方には地形次第几陵夷し螕かに寒風山 $(354.7 \mathrm{~m})$ が隆出与うのみであり，その沿岸，殊に南海岸には段丘の弡澾が 箸しい。

地質も地形上相呼隹し，西方の背斜附近は流紋岩その他の火山崔，及び

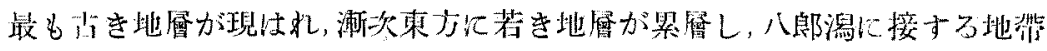

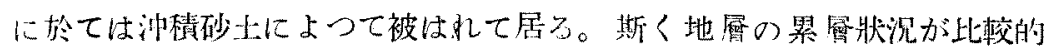
朋眿に連續關係を示す點に於て，多鹿統は油时地質の標式として學者の汸 意を悉き來つた譯である1!。

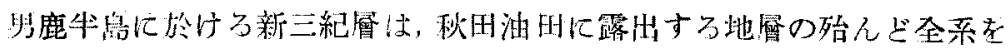

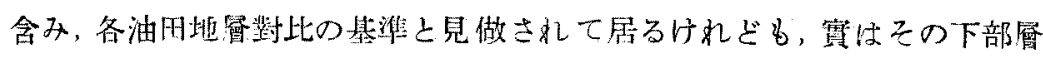

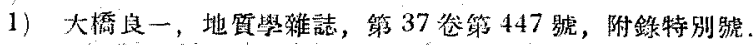

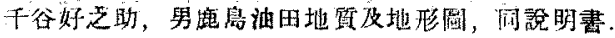

